\title{
Wound Care with Euphorbia Honey after Nucleation: A Case Report
}

Khiati $\mathbf{B}^{1}$, Bacha $\mathbf{S}^{1,2}$, Ahmed $\mathbf{M}^{1,2 *}$, Aissat $\mathbf{S}^{1,2}$, Meslem $\mathbf{A}^{1,2}$ and Djebli $\mathbf{N}^{2}$

${ }^{1}$ Institute of Veterinary Sciences University Ibn-Khaldoun, Tiaret, Algeria

${ }^{2}$ Pharmacognosy \& Api-Phytotherapy Research Laboratory, Mostaganem University, Algeria

\begin{abstract}
Honey has been used on wounds since ancient times. The present case report describes the post-operative care of an infected wound by use of honey. The wound was first cleaned with saline, and then the honey ointment was applied gently to the wound, using a glove. Granulation tissue and epithelisation were growing quickly and without complications, and scar formation was fine. Euphorbia honey applied was selected according to their antiinflammatory, analgesic, and antibacterial capacity as well as their capacity to promote wound healing.
\end{abstract}

Keywords: Euphorbiahoney; Wounds; Algeria

\section{Introduction}

The increased interest in complementary therapies has led to the investigation of products traditionally believed to have a beneficial effect in wound healing. Honey presents plenty of biological and pharmacological properties, such as immunomodulatory, antiinflammatory, debriding action, antioxidant, antibacterial, activities, among others [1-7]. The efficiency and efficacy of the topical application of honey on burns have been reported by previous study [8-10]. Euphorbia honey is a type of honey produced locally in Algeria. Therefore, the present study showed that topical application of Euphorbia honey eye enucleation in cow.

\section{Treatment Plan}

The wound was first cleaned with saline, and then the honey ointment was applied gently to the wound, using a glove. The wound was not covered by a secondary dressing. For the first days the wound was treated one to two times a day (Figure-1).

\section{Discussion}

Enucleation is one of the most common orbital surgical procedures performed in cattle [11]. Wounds are of great concern in animals as they affect animal productivity and their treatment represents an economic burden to the owners particularly in developing countries $[12,13]$. Many studies have been carried on the effectiveness of honey in promoting the healing of standardised wounds created on experimental animals $[14,15]$. Bang and coworkers [16] described the antibacterial

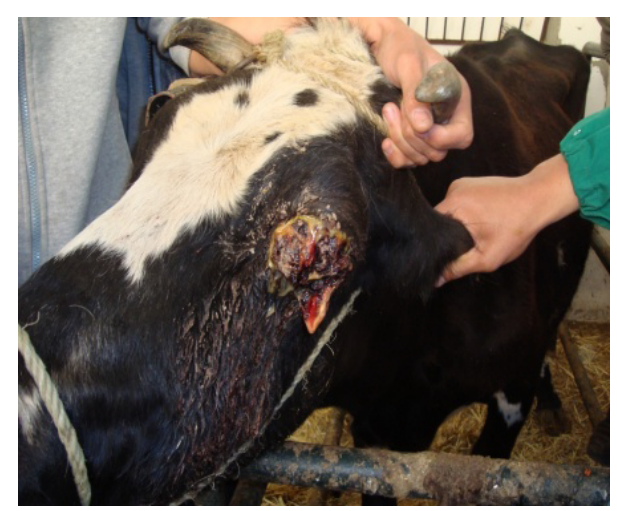

Figure 1: 19May, 2013-Wound directly after the accident. effect of honey as a result of hydrogen peroxide production by glucose oxidase in the wound. In addition, the hydrogen peroxide contained at low levels in honey also stimulates angiogenesis [17]. Efem [18] in a study reported that honey debrided wounds rapidly, replacing sloughs with granulation tissue. Honey is mildly acidic and has a $\mathrm{pH}$ between 3 and 4 Topical acidification of wounds promotes healing [19]. The glucose content of honey would also explain the very rapid removal of malodour from infected wounds that results when wounds are dressed with honey [20]. Honey has been shown to enhance granulation tissue formation and epithelialization, possibly via their stimulatory activity on the tissue macrophage [20]. Honey also provides antioxidants which protect wound tissues from the damage imparted by free oxygen radicals released from inflammatory cells. In our case after application of Euphorbia honey, after debridement, resulted in relieving edema and inflammation around the wound, remarkable decrease of exudation from the wound, disappearance of infection and observable decrease of wound surface after one week and significant reduction in wound size after 2 weeks of treatment (Figures 2-4). In conclusion, Algerian honey was beneficial in healing of traumatized wounds in cattle.

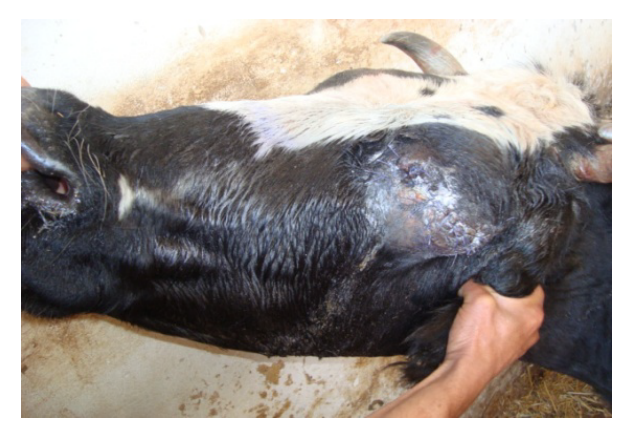

Figure 2: 22May, 2013 - eyeafter 4 days of honey treatment.

*Corresponding author: Ahmed Moussa, Institute of Veterinary Sciences University Ibn-Khaldun, Tiaret, Algeria, Tel: +213 65234059; Fax: +213 46 425001; E-mail: moussa7014@yahoo.fr

Received August 04, 2013; Accepted August 23, 2013; Published August 26 , 2013

Citation: Khiati B, Bacha S, Ahmed M, Aissat S, Meslem A, Djebli N (2013) Wound Care with Euphorbia Honey after Nucleation: A Case Report. Clin Microbial 2: 129. doi: 10.4172/2327-5073.1000129

Copyright: ( $) 2013$ Khiati B, et al. This is an open-access article distributed under the terms of the Creative Commons Attribution License, which permits unrestricted use, distribution, and reproduction in any medium, provided the original author and source are credited. 
Citation: Khiati B, Bacha S, Ahmed M, Aissat S, Meslem A, Djebli N (2013) Wound Care with Euphorbia Honey after Nucleation: A Case Report. Clin Microbial 2: 129. doi: 10.4172/2327-5073.1000129

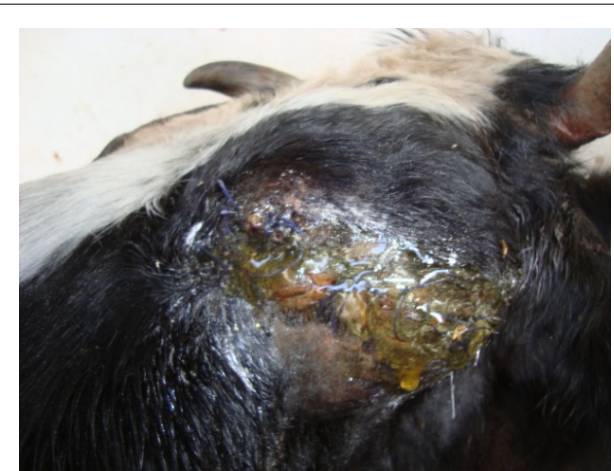

Figure 3: 28 May, 2013-eyeafter 10 days of honey treatment.

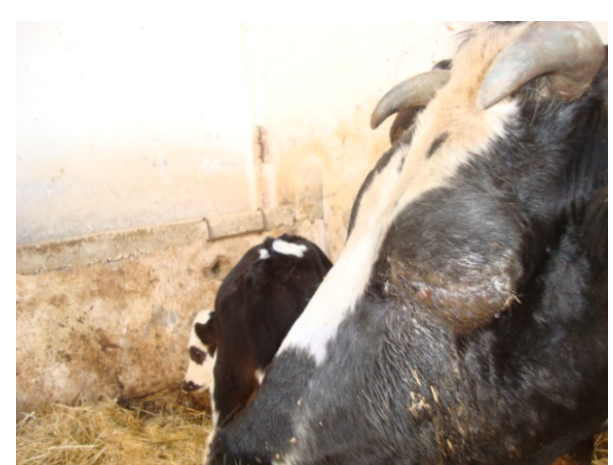

Figure 4: 30May, 2013 - eyeafter12 days of honey treatment.

\section{Acknowledgments}

This work was financially supported by project CNEPRU,Institute of Veterinary Sciences, University Ibn-Khaldoun (TIARET), Algeria (Grant No. I023201012 /2010).

\section{Foundation Project}

Supported by project CNEPRU, Institute of Veterinary Sciences,University Ibn-Khaldoun (TIARET), Algeria (Grant No. 1023201012/2010).

\section{References}

1. Saxena S, Gautam S, Sharma A (2010) Physical, biochemical and antioxidantproperties of some Indian honeys. Food Chem 118: 391-397.

2. Alvarez-Suarez JM, Tulipani S, Romandini S, et al (2010) Contribution of honey in nutrition and human health: a review. Mediterr J Nutr Metab 3: 15-23.

3. Ha SK, Moon E, Kim SY (2010) Chrysin suppresses LPS-stimulated proinflammatory responses by blocking NF-10 ${ }^{\circ} \mathrm{B}$ and JNK activations in microglia cells. Neurosci Lett 485: 143-147.
4. Najafi M, Gharakhani A, Oskouei TE (2011) Protective effect of pharmacologic postconditioning with natural honey against left ventricular ischemia/ reperfusion-induced arrhythmias in isolated heart of rat. Physiol Pharmacol 14: 406-415.

5. Ahmed M, Djebli N, Aissat S, Khiati B, Ünal M, et al. (2012) Antiradical Activity and Total Phenolics of Algerian Honeys and Antibacterial Effect Against GramNegative Bacteria. J Microb Biochem Technol 4: 152-156.

6. Ahmed M, Saad A, Djebli N (2012) How Honey Acts as an Antioxidant? Med Aromat Plants 1: 5

7. Al-Waili N, Salom K, Al-Ghamdi AA (2011) Honey for wound healing, ulcers and burns; data supporting its use in clinical practice. ScientificWorldJournal 11: 766-787.

8. Lee DS, Sinno S, Khachemoune A (2011) Honey and wound healing: an overview. Am J Clin Dermatol 12: 181-190.

9. Lund-Nielsen B, Adamsen L, Gottrup F, Rorth M, Tolver A, et al. (2011) Qualitative bacteriology in malignant wounds--a prospective, randomized, clinical study to compare the effect of honey and silver dressings. Ostomy Wound Manage 57: 28-36.

10. Lund-Nielsen B, Adamsen L, Kolmos HJ, Rørth M, Tolver A, et al. (2011) The effect of honey-coated bandages compared with silver-coated bandages on treatment of malignant wounds-a randomized study. Wound Repair Regen 19: 664-670.

11. Vermunt J (1984) Transpalpebral exenteration in cattle. Vet Q 6: 46-48.

12. Fukuda M, Kobayashi K, Hirono $\mathrm{Y}$, Miyagawa M, Ishida T, et al. (2011) Jungle honey enhances immune function and antitumor activity. Evid Based Complement Alternat Med 2011: 908743.

13. Iftikhar F, Arshad M, Rasheed F, Amraiz D, Anwar P, et al (2010) Effects of acacia honey on wound healing in various rat models. Phytother Res 24: 583586

14. Nisbet HO, Nisbet C, Yarim M, Guler A, Ozak A (2010) Effects of three types of honey on cutaneous wound healing. wounds 22: 275-283.

15. Haryanto, Urai T, Mukai K, Suriadi, Sugama J, et al. (2012) Effectiveness of Indonesian honey on the acceleration of cutaneous wound healing: an experimental study in mice. wounds 24: 110-119.

16. Bang LM, Buntting C, Molan P (2003) The effect of dilution on the rate of hydrogen peroxide production in honey and its implications for wound healing. J Altern Complement Med 9: 267-273.

17. Mohd Zohdi R, Abu Bakar Zakaria Z, Yusof N, Mohamed Mustapha N, Abdullah MN (2012) Gelam (Melaleuca spp.) Honey-Based Hydrogel as Burn Wound Dressing. Evid Based Complement Alternat Med 2012: 843025.

18. Efem SE (1988) Clinical observations on the wound healing properties of honey. Br J Surg 75: 679-681.

19. Molan PC (1999) The role of honey in the management of wounds. J Wound Care 8: 415-418.

20. Ghaderi R, Afshar M, Akhbarie H, Golalipour MJ (2010) Comparison of the Efficacy of Honey and Animal Oil in Accelerating Healing of Full Thickness Wound of mice skin. Int J Morphol 28: 193-198. 